\title{
A patient with primary gastric choriocarcinoma who received a correct preoperative diagnosis and achieved prolonged survival
}

\author{
Tsuyoshi Noguchi ${ }^{1}$, Shinsuke Takeno $^{1}$, Tetsuro Sato ${ }^{1}$, Yoshiaki Takahashi ${ }^{1}$, Yuzo Uchida ${ }^{1}$, \\ and SHIGEO YoKoYAMA ${ }^{2}$ \\ ${ }^{1}$ Department of Surgery II, Oita Medical University, 1-1 Idaigaoka, Hasama-machi, Oita 879-5593, Japan \\ ${ }^{2}$ Department of Pathology, Oita Medical University, Oita, Japan
}

\begin{abstract}
Primary choriocarcinoma of the stomach is an extremely rare and highly malignant tumor. A 68-year-old Japanese man was admitted to our department with symptoms of epigastric pain, abdominal fullness, and dizziness. Primary gastric choriocarcinoma with regional lymph node metastases was diagnosed preoperatively by the detection of elevated serum levels of a tumor marker, radiography, and immunohistochemical staining of biopsy specimens. The patient underwent total gastrectomy and jejunal reconstruction (Roux-en-Y method), followed by chemotherapy. Histological examination of the resected stomach revealed typical choriocarcinoma accompanied by common adenocarcinomatous elements. After postoperative chemotherapy the patient survived for 4 years and 6 months, and died with no evidence of recurrence of carcinoma. This is the first known patient with primary gastric choriocarcinoma to have survived for such a long period without recurrent elevation of the serum level of human chorionic gonadotropin (HCG), which was a useful marker when reevaluating the patient.
\end{abstract}

Key words Primary gastric choriocarcinoma $\cdot$ Long-term survival · Total gastrectomy

\section{Introduction}

Choriocarcinoma is a rapidly growing and widely metastatic epithelial neoplasm, derived from either trophoblastic or totipotential germ cells [1]. In most cases, the tumor arises from chorionic villi in association with normal and abnormal gestation [2], including ectopic pregnancy [3]. Choriocarcinoma may also occur as a primary neoplasm of the ovary [4] or testis [5]. Primary choriocarcinoma of the stomach is extremely rare, and most such cases are not diagnosed correctly before operation.

Offprint requests to: T. Noguchi

Received: October 22, 2001 / Accepted: February 22, 2002
Furthermore, most patients with primary choriocarcinoma of the stomach do not survive for even 1 year after operation, so the prognosis is considerably worse than that of common gastric adenocarcinoma. We report a patient with primary choriocarcinoma of the stomach who received a correct diagnosis preoperatively and who survived for 4 years and 6 months after operation.

\section{Case report}

A 68-year-old Japanese man was referred to the Second Department of Surgery at Oita Medical University, on April 12, 1994. He had been suffering for 1 month from epigastric pain, abdominal fullness, and dizziness. His only significant past medical history was hypertension, requiring treatment with a calcium channel blocker. He had three healthy children. The family history was essentially negative for familial or hereditary disease, but his elder brother had died of gastric cancer.

On examination, the patient was pale because of severe anemia, and had an ill-defined mobile epigastric mass, approximately $5 \mathrm{~cm}$ by $10 \mathrm{~cm}$ in size. Supraclavicular lymph nodes were not palpable, and the testes and breasts were normal. Initial laboratory study results were normal, except for hemoglobin, at $8.7 \mathrm{~g} / \mathrm{dl}$, and a hematocrit of $26.6 \%$ (Table 1). Radiographic examination of the upper gastrointestinal tract demonstrated a large tumor in the gastric body and antrum with an annular stricture. There were scirrhous changes of the gastric wall and an absence of gastric folds, thus raising a suspicion of Borrmann type IV cancer. As to tumor markers, serum carcinoembryonic antigen (CEA), alpha-fetoprotein (AFP), and carbohydrate antigen (CA)-19-9 levels were within normal limits. Gastric fiberscopy revealed a large tumor occupying the gastric body and antrum, with a mixture of protruding and ulcerative lesions, accompanied by areas of hemorrhage. 


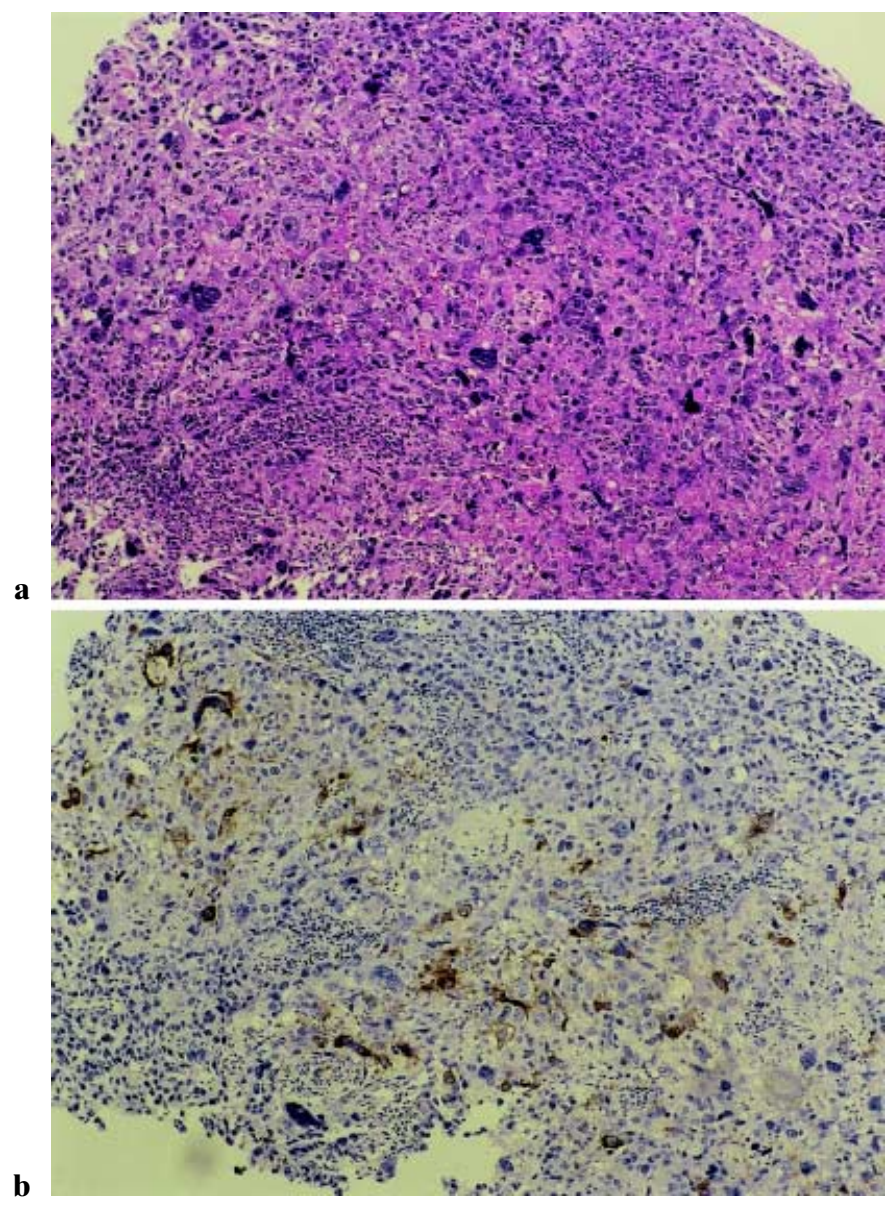

Fig. 1a,b. Histological findings of the biopsy specimen. a Strongly atypical cells are arranged densely with a sheet-like appearance. b Immunohistochemical staining against human chorionic gonadotropin (hCG)- $\beta$. The specimen is studded with immunopositive cancer cells. a H\&E, $\times 90$; b $\times 90$

Biopsy specimens were interpreted as showing adenocarcinoma with choriocarcinomatous differentiation, using hematoxylin and eosin (H\&E) staining and immunohistochemistry (Fig. 1a,b). Levels of human chorionic gonadtropin ([hCG]-enzyme immunoassay [EIA]) and its beta-subunit (hCG- $\beta$ ) in the serum and in the urine were extremely high (Table $1)$.

\section{Operative findings (according to the Japanese classification of gastric carcinoma, 2nd English edition) [6]}

The patient underwent total gastrectomy on April 20, 1994, with the preoperative diagnosis of primary gastric choriocarcinoma. Liver metastasis, peritoneal dissemination, and ascites were not investigated ( $\mathrm{H} 0, \mathrm{P} 0)$, and distant metastasis to other organs was not present (M0).

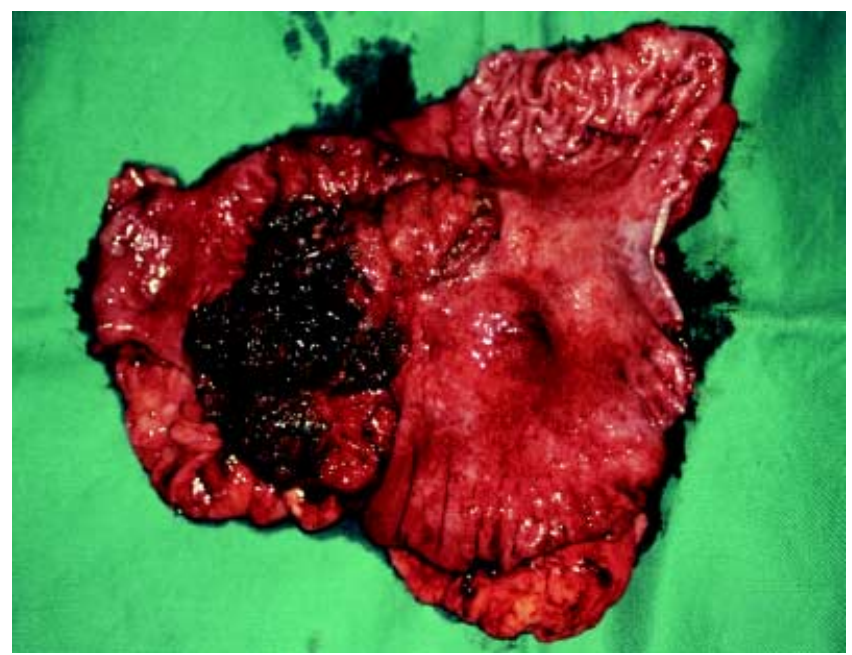

Fig. 2. Gross view of the resected stomach

Table 1. Laboratory data on admission

$\begin{array}{ll}\text { WBC } 10700 / \mu \mathrm{l} & \text { TP } 6.88 \mathrm{~g} / \mathrm{dl} \\ \mathrm{RBC} 316 \times 10^{4} / \mu \mathrm{l} & \text { Alb } 3.31 \mathrm{~g} / \mathrm{dl} \\ \mathrm{Hb} 8.7 \mathrm{~g} / \mathrm{dl} & \text { T-Bil 0.33 g/dl } \\ \text { Ht } 26.6 \% & \text { GOT 20.9IU/1 } \\ \text { Plt } 36.7 \times 10^{4} / \mu \mathrm{l} & \text { GPT } 12.6 \mathrm{IU} / 1\end{array}$

CEA $1.1 \mathrm{ng} / \mathrm{ml}$ (normal, $<5 \mathrm{ng} / \mathrm{ml})$ CA19-9 12.6U/ml (normal, $<36.4 \mathrm{U} / \mathrm{ml}$ ) AFP $0.8 \mathrm{ng} / \mathrm{ml}$ (normal, 0-20 ng/ml) Serum hCG $140 \mathrm{ng} / \mathrm{ml}$ (normal, $<0.1 \mathrm{ng} / \mathrm{ml}$ ) Serum hCG-EIA $8100 \mathrm{mIU} / \mathrm{ml}$ (normal, $<0.7 \mathrm{mIU} / \mathrm{ml}$ ) Urine hCG $55 \mathrm{ng} / \mathrm{ml}$ (normal, <0.1 ng/ml)

hCG, Human chorionic gonadotropin; EIA, enzyme immunoassay

There was an invasive tumor encircling the gastric body and antrum. Macroscopic lymph node metastasis was seen at the following lymph nodes (LN): right paracardial (no. 1); LN along the lesser curvature (no. 3); suprapyloric LN (no. 5); infrapyloric LN (no. 6); LN along the left gastric artery (no. 7); and LN along the common hepatic artery (no. 8a) (N3). These lymph nodes were connected with each other, forming a nodular mass and infiltrating to the pancreas (T4). The operative staging group was stage IVb (H0P0N3T4M0). Total gastrectomy with D3 lymph node dissection (nos. $1,2,3,4,5,6,7,8,9,10,11,12,13,14)$, cholecystectomy, and splenectomy were performed, and the lesion of lymph nodes infiltrating the pancreas was removed using an electric knife. The Roux-en-Y method of reconstruction was performed after resection. At the conclusion of surgery, the curative potential of resection was "resection B"; namely, definite residual disease was not present. 


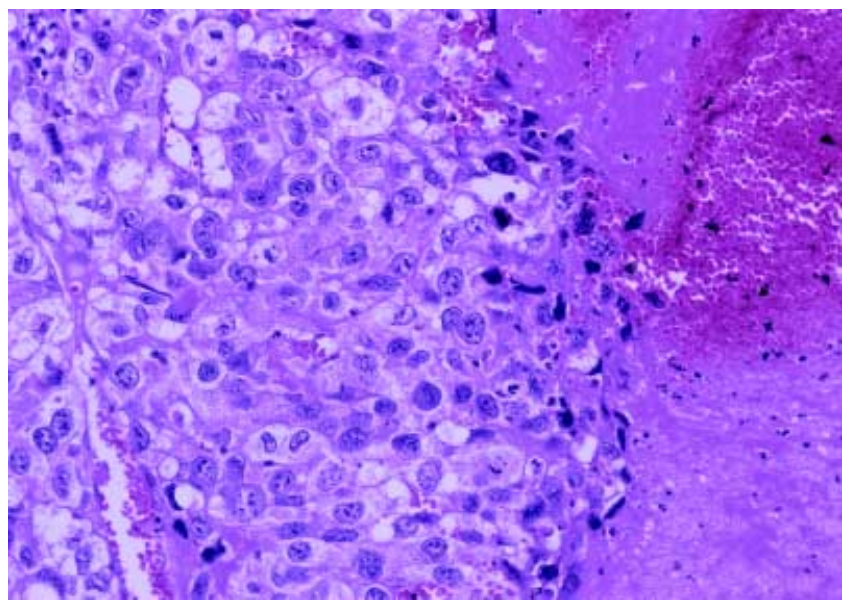

Fig. 3. Massive numbers of tumor cells are present, with hemorrhage and necrosis. The tumor nest consists of cytotrophoblasts with large, atypical nuclei and peripheral streaming of syncytiotrophoblastic elements. H\&E, $\times 490$

\section{Pathological findings}

The tumor was $10 \mathrm{~cm}$ by $12 \mathrm{~cm}$ in size, irregularly shaped but relatively limited to the body and prepylorus of the stomach. Almost half of the tumor demonstrated villous growth, with some bleeding areas (Fig. 2).

Under low magnification with H\&E staining, cell proliferation demonstrated a sheet-like appearance, with many foci of hemorrhage and necrosis being observed. Under high magnification (Fig. 3), tumor cells exhibited two histologic types: "cytotrophoblastic cells", with large, oval nuclei; and "syncytiotrophoblastic cells" with bizzare nuclei. The mixture of these cells was investigated.

Most of the neoplastic cells, especially the syncytiotrophoblastic cells, showed strong immunohistochemical staining against anti-hCG ( $\alpha$ and $\beta$ ). The metastatic cells in the lymph nodes were stained similarly.

Histologically, tubulo-papillary adenocarcinoma was also seen in some areas, although most of the tumor was choriocarcinoma, which demonstrated strong reactivity against anti-hCG antibody. These two types of carcinomas were closely adjoining each other (Fig. 4a). We could easily recognize the borderline between the choriocarcinomatous and adenocarcinomatous components by immunohistochemical staining, using anti CEA antibody, as the adenocarcinoma stained positively, but the choriocarcinoma did not (Fig. 4b).

\section{Postoperative course (Fig. 5)}

Postoperative chemotherapy was performed, employing the same regimen as that used for advanced gastric
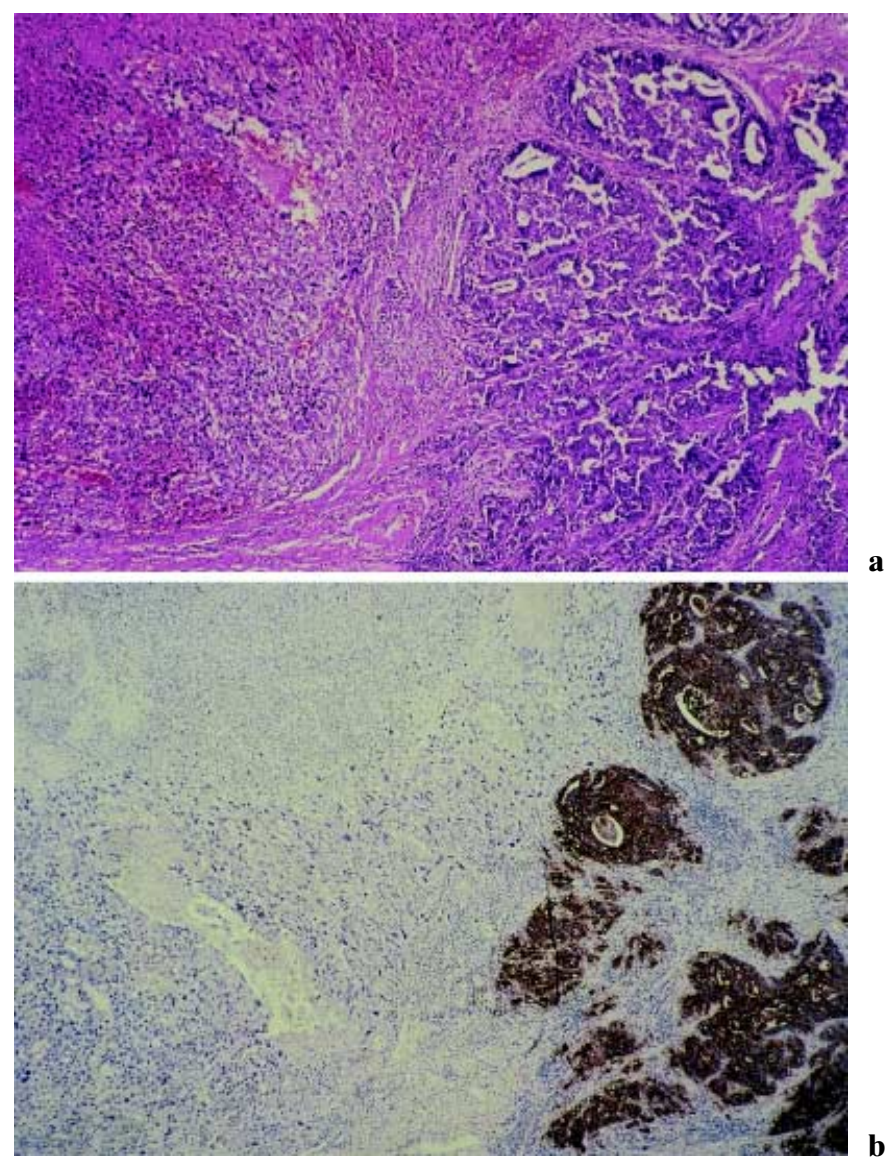

Fig. 4. a Microscopic view of the borderline between choriocarcinoma (ch) and adenocarcinoma (ad). b Carcinoembryonic antigen (CEA) immunostaining of section continuous with the $\mathrm{H} \& \mathrm{E}$ staining in a. a $\mathrm{H} \& \mathrm{E}, \times 40 ; \mathbf{b} \times 40$

adenocarcinoma at our department. Intravenous injections of mitomycin C (MMC) were given as $20 \mathrm{mg}$ on the day of operation and $10 \mathrm{mg}$ on the next day. The subsequent treatment consisted of three cycles of 5fluorouracil (5-FU) and cisplatin (CDDP), given once a month. Each treatment cycle included 5-FU $750 \mathrm{mg} /$ day on days 1 to 5 , as a 24-h continuous drip infusion, and CDDP $75 \mathrm{mg} /$ day on day 1 , as a 5-h drip infusion. After the three cycles of CDDP and 5-FU, the patient received uracil and futrafur (UFT) orally. The dose of UFT was $600 \mathrm{mg} /$ day. No side effects, other than leukopenia, were seen during the chemotherapy over a period of 27 months.

The patient came to see us monthly. Serum hCG, which we employed as a tumor marker, was measured at each visit. No re-elevation of serum hCG was ever seen and no liver or lymph node metastases were detected on thoraco-abdominal computed tomography scans.

The patient ultimately died of restrictive lung disease 4 years and 6 months after the surgery. 


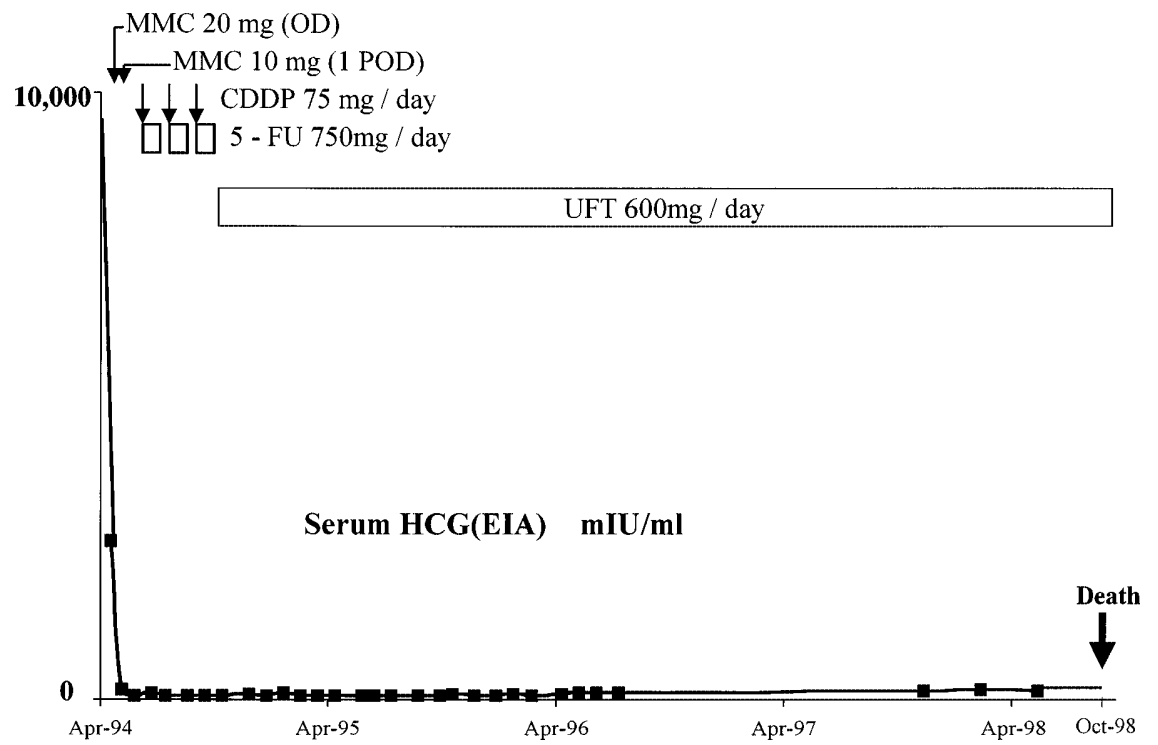

Fig. 5. Patient's clinical course, indicating the postoperative chemotherapy and the serum human chorionic gonadotropin (HCG) level. $M M C$, mitomycin $\mathrm{C}, O D$, operative day; $P O D$, postoperative day; $C D D P$, cisplatin; 5-FU, 5-fluorouracil; $E I A$, enzyme immunoassay; UFT, futrafur

Table 2. A summary of cases of primary gastric choriocarcinoma reported in the past 20 years

\begin{tabular}{|c|c|c|c|c|c|}
\hline First author and year & $\begin{array}{l}\text { Age (years), } \\
\text { sex }\end{array}$ & $\begin{array}{c}\text { Preoperative } \\
\text { diagnosis }\end{array}$ & Coexistence & Operation & Outcome (survival) \\
\hline Smith (1980) [13] & $23, \mathrm{~F}$ & Yes & Yes & No & Several weeks \\
\hline Wurzel (1981) [14] & $51, \mathrm{~F}$ & No & No & No & 1 Month \\
\hline \multirow[t]{2}{*}{ Saigo (1981) [15] } & $56, \mathrm{~F}$ & Adenocarcinoma & Yes & Yes & 4 Months \\
\hline & $67, \mathrm{~F}$ & No & Yes & Yes & 5 Weeks \\
\hline \multirow[t]{2}{*}{ Mori (1982) [16] } & $42, \mathrm{M}$ & Poorly diff. adenoca. & Yes & Yes & 3 Months \\
\hline & $41, \mathrm{M}$ & $\begin{array}{l}\text { Moderately diff. } \\
\text { adenoca. }\end{array}$ & Yes & Yes & 11 Months \\
\hline Garcia (1985) [17] & $65, \mathrm{M}$ & No & Yes & No (autopsy) & 40 Days \\
\hline Fukuda (1985) [18] & $70, \mathrm{~F}$ & Adenocarcinoma & Yes & No (autopsy) & 6 Months \\
\hline $\begin{array}{l}\text { Chandrasekhara } \\
\text { (1986) [19] }\end{array}$ & $30, \mathrm{M}$ & Yes & Not mentioned & No & Bad (not mentioned) \\
\hline Ramponi (1986) [20] & $73, \mathrm{M}$ & No & Yes & Yes & Not mentioned \\
\hline Okada (1987) [21] & $55, \mathrm{M}$ & No & No & $\begin{array}{l}\text { No (gastrojejunostomy } \\
\text { only) }\end{array}$ & 4 Months \\
\hline Krulewski (1988) [22] & $62, \mathrm{M}$ & Adenocarcinoma & Yes & Yes & 9 Months \\
\hline Matsunage (1989) [23] & $58, \mathrm{~F}$ & No & Not mentioned & No (autopsy) & Refractory \\
\hline Gorczyca (1992) [24] & $71, \mathrm{~F}$ & Adenocarcinoma & No & Yes & Not mentioned \\
\hline Motoyama (1994) [25] & $46, \mathrm{~F}$ & No & Yes & Yes & 12 Months \\
\hline Imai (1994) [26] & $63, \mathrm{M}$ & Adenocarcinoma & Yes & Yes & 88 Days \\
\hline Bateman (1995) [27] & $80, \mathrm{M}$ & Undifferentiated ca. & Not mentioned & No & 4 Months \\
\hline Jan (1997) [28] & $71, \mathrm{~F}$ & No & Yes & Yes & 23 Days \\
\hline Coskum (1998) [29] & $37, \mathrm{~F}$ & Chorioca. compatible & Yes & No (chemotherapy) & Not mentioned \\
\hline Present patient & $68, \mathrm{M}$ & Choriocarcinoma & Yes & Yes & 4 Years and 6 months \\
\hline
\end{tabular}

Preoperative diagnosis: yes, Choriocarcinoma; no, biopsy was not done; coexistence: yes, coexistent with common adenocarcinoma (adenoca.); no, choriocarcinoma (chorioca.) only; diff., differentiated

\section{Discussion}

Choriocarcinoma can be gonadal or extragonadal in origin, and occurs most frequently in the uterus in association with pregnancy. The most common sites for extragonadal tumors are the mediastinum [7], ovary [4] and testis [5]. Primary choriocarcinoma of the stomach is extremely rare, although metastatic choriocarcinoma to the stomach has been reported numerous times [8-10]. To date, about 40 cases of primary choriocarcinoma of the stomach have been reported in the English-language literature, following the first descriptions by Davidsohn (in German) [11] and Helmholz [12]. We reviewed 19 cases reported in the Englishlanguage literature after 1980 (Table 2) [13-29]. The mean age of the patients was 55 years, ranging from 23 to 80 years. Nine patients were male and ten were female. 
We describe here a well-documented case of primary gastric choriocarcinoma, as supported by the following evidence. First, no cancer lesions were found elsewhere in the patient besides the stomach. Second, the tumor histology itself was that of choriocarcinoma in all sites, showing immunohistochemical positivity of the tumor cells against hCG antibody. Finally, extremely high levels of serum hCG and urine hCG were detected preoperatively, but these levels decreased to within normal limits after total gastrectomy and chemotherapy.

There are several theories of the histopathogenesis of primary gastric choriocarcinoma. These hypotheses include; histological resemblance to choriocarcinoma [30], origin from a gonadal anlage displaced in the abdomen [11], presence as a long-delayed metastasis from a genital primary lesion [31], origin from an underlying gastric teratoma [32], and the retrodifferentiation or opisthoplasia of carcinoma cells to the level of the embryonal ectoderm with the ability to form trophoblasts [33]. In support of the retrodifferentiation theory are the findings that gastric choriocarcinomas are frequently accompanied by adenocarcinoma or other elements, and occasionally show a transitional form between adenocarcinoma and choriocarcinoma. In addition, gastric choriocarcinoma shows a similarity to gastric adenocarcinoma in age and sex distributions. For these reasons, several contemporary investigators have accepted the retrodifferentiation theory, which showed a retrodifferentiation of the adenocarcinoma cells to the level of the embryonal ectoderm and, subsequently, a metaplasia or disdifferentiation to trophoblastic precursor cells.

In the present patient, the authors wish to stress two points. First, the tumor was correctly diagnosed before operation by the pathological examination of biopsy specimens, unlike most of the previously reported cases that we reviewed. Of the 19 patients whose cases were reviewed in this report, only 3 patients were correctly diagnosed as having gastric choriocarcinoma. Perhaps clinicians should take more biopsy specimens when encountering large and hemorrhagic tumors, in order to correctly diagnose gastric choriocarcinoma.

Second, our patient survived for 4 years and 6 months after operation. As many case reports mention [13-29], primary gastric choriocarcinoma exhibits extremely high malignancy, and most patients die within 1 year after diagnosis. Our patient had a prolonged survival after undergoing gastrectomy followed by a common chemotherapy regimen often employed in gastric adenocarcinoma $[34,35]$. The patient ultimately died of lung disease without any re-elevation of serum hCG level. We therefore believe that the patient was cured of his choriocarcinoma.

In conclusion, we treated a patient with primary gastric choriocarcinoma successfully. From this experience, we recommend radical operation and combined chemotherapy for such a carcinoma. There is no established regimen of chemotherapy for primary gastric choriocarcinoma, but we suggest 5-FU and CDDP combination therapy, based on our experience with this patient.

\section{References}

1. Brewer JI, Smith RT, Pratt GB. Absolute 5-year survival rates of 122 patients treated by hysterectomy. Am J Obstet Gynecol 1963;85:841-3.

2. Berkowitz RS, Im SS, Bernstein MR, Goldstein DP. Gestational trophoblastic disease. Subsequent pregnancy outcome, including repeat molar pregnancy. J Reprod Med 1998;43:81-6.

3. Honigl W, Reich O, Ranner G, Pickel H. Choriocarcinoma of the uterus after term pregnancy: imaging by vaginal color Doppler ultrasound. Ultraschall Med 1997;18:165-8.

4. Gerbie MV, Brewer JI, Tamimi H. Primary choriocarcinoma of the ovary. Obstet Gynecol 1975;46:720-3.

5. Schill H, Arborio M, Gros P, Grippari JL. Pathologic anatomy of tumors of the testis. Arch Anat Cytol Pathol 1992;40:195201.

6. Japanese Gastric Cancer Association. Japanese classification of gastric carcinoma. 2nd English ed. Gastric Cancer 1998;1:10-24.

7. Moran CA, Suster S. Primary mediastinal choriocarcinomas: a clinicopathologic and immunohistochemical study of eight cases. Am J Surg Pathol 1997;21:1007-12.

8. Fleck RM, Schade RR, Kowal CD, Van Thiel DH. Testicular choriocarcinoma with metastasis to gastric mucosa. Gastrointest Endosc 1984;30:188-9.

9. Eskreis D, Zinberg J, Manzione NC, Jones J. Metastatic choriocarcinoma to the stomach presenting as hematemesis. Dig Dis Sci 1988;33:247-50.

10. Lombard F, Burtin P, Ketani S, Delaby J, Cales P, Boyer J. Mediastinal posterior choriocarcinoma with hemorrhagic gastric metastasis: endosonographic features. Gastrointest Endosc 1992; 38:187-90.

11. Davidsohn C. Chorion-Epitheliom und Magenkrebs, eine seltene Verschmelzung zweier bösartiger Geschwülste. Charite-Annal 1905;29:426-37.

12. Helmholz HF. A syncytiomatous tumor of the stomach. Bull Johns Hopkins Hospital 1907;18:376-9.

13. Smith FR, Barkin JS, Hensley G. Choriocarcinoma of the stomach. Am J Gastroenterol 1980;73:45-8.

14. Wurzel J, Brooks JJ. Primary gastric choriocarcinoma: immunohistochemistry, postmortem documentation, and hormonal effects in a postmenopausal female. Cancer 1981;48:275661.

15. Saigo PE, Brigati DJ, Sternberg SS, Rosen PP, Turnbull AD. Primary gastric choriocarcinoma: an immunohistological study. Am J Surg Pathol 1981;5:333-42.

16. Mori H, Soeda O, Kamano T, Tsunekawa K, Ueda N, Yoshida A, et al. Choriocarcinomatous change with immunocytochemically HCG-positive cells in the gastric carcinoma of the males. Virchows Arch A Pathol Anat 1982;396:141-53.

17. Garcia RL, Ghali VS. Gastric choriocarcinoma and yolk sac tumor in a man: Observations about its possible origin. Hum Pathol 1985;16:955-8.

18. Fukuda Y, Sakurai M, Matsuura N. Primary gastric choriocarcinoma; report of an autopsy case with immunohistochemical study. Acta Pathol Jpn 1985;35:655-66.

19. Chandrasekhara KL, Galifianakis GN. Case report: choriocarcinoma of the stomach. MD Med J 1986;35:49.

20. Ramponi A, Angeli G, Arceci F, Pozzuoli R. Gastric choriocarcinoma; an immunohistochemical study. Pathol Res Pract 1986; 181:390-6. 
21. Okada K, Yokoyama S, Mochizuki Y, Moriuchi A, Yamashita H, Yasunaga A, et al. An autopsy case of primary gastric choriocarcinoma. Jpn J Clin Oncol 1987;17:263-73.

22. Krulewski T, Cohen LB. Choriocarcinoma of the stomach: pathogenesis and clinical characteristics. Am J Gastroenterol 1988;83:1172-5.

23. Matsunaga N, Hayashi K, Futagawa S, Fukuda T, Takahara O, Yoshida K, et al. Primary choriocarcinoma of the stomach presenting as gastrointestinal hemorrhage: report of a case. Radiation Med 1989;7:220-2.

24. Gorczyca W, Woyke S. Endoscopic brushing cytology of primary gastric choriocarcinoma. Acta Cytologica 1992;36:551-4.

25. Motoyama T, Aizawa K, Fujiwara T, Endoh Y, Watanabe H. Coexistence of choriocarcinoma and hepatoid adenocarcinoma in the stomach. Pathol Int 1994;44:716-21.

26. Imai Y, Kawabe T, Takahashi M, Matsumura M, Komatsu Y, Hamada E, et al. A case of primary gastric choriocarcinoma and a review of the Japanese literature. J Gastroenterol 1994;29:6426.

27. Bateman HE, Kasimis BS, Yook CR, Hiremath V. Case report: primary choriocarcinoma of the stomach. N J Med 1995;92:45962.
28. Jan YJ, Chen JT, Ho WL, Wu CC, Yeh DC. Primary coexistent adenocarcinoma and choriocarcinoma of the stomach. J Clin Gastroenterol 1997;25:550-4.

29. Coskum M, Agildere AM, Boyvat F, Tarhan C, Niron EA. Primary choriocarcinoma of the stomach and pancreas: CT findings. Eur Radiol 1998;8:1425-8.

30. Stewart MJ. Carcinoma of the stomach, with secondary deposits in the liver, some of which simulate chorionepithelioma. J Pathol Bacteriol 1913;17:409-12.

31. Koritschoner R. Über ein Chorionepitheliom ohne Primärtumor mit abnorm langer Latenzzeit. Beitr Path Anat 1920;66:501-10.

32. Hartz PH, Ramirez CA. Coexistence of carcinoma and chorioepithelioma in the stomach of a young man. Cancer 1953;6:319-26.

33. Regan JF, Cremin JH. Chorionepithelioma of the stomach. Am J Surg 1960;100:224-33.

34. Imanaga $H$, Nakazato $H$. Results of surgery for gastric cancer and effect of adjuvant mitomycin $\mathrm{C}$ on cancer recurrence. World $\mathrm{J}$ Surg 1977;1:213-21.

35. Lacave AJ, Baron FJ, Anton LM, Estrada E, De Sande LM, Palacio I, et al. Combination chemotherapy with cisplatin (CDDP) and 5-fluorouracil 5-day infusion in the therapy of advanced gastric cancer: a phase II trial. Ann Oncol 1991;2:751-4. 